\title{
Fractured neck of femur and contralateral intracerebral lesions
}

\author{
J MCCLURE, SUSAN GOLDSBOROUGH
}

From the Department of Histopathology, University Hospital of South Manchester, Manchester

SUMMARY Ten cases of fractured neck of femur studied at necropsy were found to have established contralateral intracerebral lesions. These were mainly infarcts, and it is suggested that the presence of hemiparesis predisposes to a fall on to the affected side and that the body weight acts through the hip joint in such a way as to fracture the femoral neck. This may happen irrespective of the magnitude of the patient's trabecular bone volume, but in osteoporotic subjects the fracture will probably be intertrochanteric, whereas in non-osteoporotic patients it will probably be subcapital.

Fractures of the proximal femur represent a considerable threat to the health of our aging population. In the United Kingdom some 40000 new patients will suffer a fracture of the femoral neck each year, about $70 \%$ of these will be subjected to operative treatment with pinning and plating, or the implantation of a prosthesis. ${ }^{1}$ It is generally appreciated that without active treatment the outlook is poor and mortality is high. It is perhaps not so widely appreciated that even with active treatment up to $27 \%$ of patients will die in the first year and about $50 \%$ of survivors remain unable to walk without assistance. ${ }^{2}$

We noted that a substantial number of cases of fractured neck of femur come to necropsy in our department, and we are currently engaged in a systematic, in depth, prospective study of the healing and tissue events associated with surgical treatment. Particular attention is being paid to the determination of the presence or absence of metabolic bone disease and other risk factors that predispose to the occurrence of the fracture, or which adversely affect the healing process. During the early course of this study we noted several cases in which there had been established intracerebral lesions.

This report looks at certain features of these cases and the role of the intracerebral lesions in the causation of the fractures.

\section{Material and methods}

Over 22 months from the beginning of 1984 to the end of October 1985 necropsies were performed on 50 patients who had sustained a fracture of the femoral neck. In $10(20 \%)$ of these established intracerebral lesions were noted, and these cases were examined in

Accepted for publication 13 March 1986 particular detail. In seven cases transiliac bone cores ( $7 \mathrm{~mm}$ diameter) were taken from the left anterior iliac crest. Undecalcified sections $(5 \mu \mathrm{m}$ thick) were prepared from these and assessed histomorphometrically for the presence of systemic metabolic bone disease.

\section{Results}

Six men and four women were included in the series. Table 1 gives some of their details. The combined median age was 78 years (range 62-91), and the $\stackrel{\varrho}{\Rightarrow}$ median ages of the men and women were 78 (range 62-82) and 81 (range 70-91) years, respectively. There were four established recent intracerebral infarcts and four old infarcts. One case showed an established intracerebellar haemorrhage. In one case there was a응 grade IV astrocytoma affecting the left parieto- 0 occipital region. Table 2 shows the sites of the intracerebral lesions and Table 3 the type and laterality of $\delta$ the femoral fractures. In each case the intracerebral lesion affected the side of the brain opposite to the $\mathrm{O}$ side of the femoral neck fracture. Although in some cases more than one intracerebral site was affected, this was always restricted to one side.

The mean time interval from the fracture to death of was 22 days with a range from one to 117 days. In N five cases the intracerebral lesions were considered, 仙 after histological examination, to have occurred at 0 or about the time of the fracture. In the five other cases the morphological features of intracerebral lesions indicated that they preceded the fracture. At necropsy there was no evidence of pulmonary or 7 intracerebral fat embolism. Table 4 gives the causes 0 of death. In all cases these were confirmed by histological examination.

In cases 3 to 10 inclusive the fracture was repaired 
Table 1 Clinical and morphological details of cases in series

\begin{tabular}{|c|c|c|c|c|c|c|c|}
\hline Case & Age & $\operatorname{Sex}$ & $\begin{array}{l}\text { Body } \\
\text { weight } \\
\text { (kg) }\end{array}$ & $\begin{array}{l}\text { Trabecular } \\
\text { bone volume } \\
\text { (left iliac crest) } \\
(\%)\end{array}$ & Fracture details & Cerebral lesion & $\begin{array}{l}\text { Clinically } \\
\text { suspected cerebral } \\
\text { lesion }\end{array}$ \\
\hline 1 & 62 & $\mathbf{M}$ & 68 & $22 \cdot 9$ & $\begin{array}{l}\text { Subcapital fracture } \\
\text { right femur }\end{array}$ & $\begin{array}{l}\text { Astrocytoma (grade IV) } \\
\text { left frontoparietal region }\end{array}$ & Yes \\
\hline 2 & 77 & $\mathbf{M}$ & 105 & $20 \cdot 4$ & $\begin{array}{l}\text { Subcapital fracture } \\
\text { left femur }\end{array}$ & $\begin{array}{l}\text { Recent infarct right } \\
\text { parieto-occipital region }\end{array}$ & Yes \\
\hline 3 & 81 & $\mathbf{M}$ & 36 & $13 \cdot 4$ & $\begin{array}{l}\text { Intertrochanteric } \\
\text { fracture left femur }\end{array}$ & $\begin{array}{l}\text { Old infarct right } \\
\text { basal ganglia }\end{array}$ & Yes \\
\hline 4 & 82 & $\mathbf{M}$ & 54 & 11.9 & $\begin{array}{l}\text { Intertrochanteric } \\
\text { fracture right femur }\end{array}$ & $\begin{array}{l}\text { Recent infarct left } \\
\text { parieto-occipital region }\end{array}$ & No \\
\hline 5 & 76 & $\mathbf{F}$ & 49 & $11 \cdot 8$ & $\begin{array}{l}\text { Intertrochanteric } \\
\text { fracture right femur }\end{array}$ & $\begin{array}{l}\text { Old infarct left } \\
\text { tempero-occipital region }\end{array}$ & No \\
\hline 6 & 70 & $\mathbf{F}$ & 55 & $6 \cdot 1$ & $\begin{array}{l}\text { Intertrochanteric } \\
\text { fracture right femur }\end{array}$ & $\begin{array}{l}\text { Recent infarct left } \\
\text { cerebellar and left } \\
\text { occipital lobes }\end{array}$ & Yes \\
\hline 7 & 91 & $\mathbf{F}$ & 34 & $5 \cdot 8$ & $\begin{array}{l}\text { Intertrochanteric } \\
\text { fracture right femur }\end{array}$ & $\begin{array}{l}\text { Old infarct left } \\
\text { internal capsule }\end{array}$ & Yes \\
\hline 8 & 80 & $\mathbf{M}$ & 46 & & $\begin{array}{l}\text { Intertrochanteric } \\
\text { fracture right femur }\end{array}$ & $\begin{array}{l}\text { Old infarct left } \\
\text { parietal region }\end{array}$ & No \\
\hline 9 & 86 & $\mathbf{F}$ & 54 & & $\begin{array}{l}\text { Intertrochanteric } \\
\text { fracture right femur }\end{array}$ & $\begin{array}{l}\text { Established haemorrhage } \\
\text { left parietal region }\end{array}$ & Yes \\
\hline 10 & 76 & $\mathbf{M}$ & 47 & & $\begin{array}{l}\text { Intertrochanteric } \\
\text { fracture left femur }\end{array}$ & $\begin{array}{l}\text { Recent infarct right } \\
\text { parietal region }\end{array}$ & Yes \\
\hline
\end{tabular}

by internal fixation. These operations were usually performed several days after admission, and examination of the anaesthetic records showed no untoward events. There were no recorded episodes of intraoperative hypotension.

The trabecular bone volume in the left iliac crest was calculated in seven cases. The mean volume was

Table 2 Site and side of intracerebral lesions

\begin{tabular}{lll}
\hline Site & Right side & Left side \\
\hline Frontal lobe & 0 & 1 \\
Temporal lobe & 0 & 1 \\
Parietal lobe & 2 & 4 \\
Occipital lobe & 1 & 3 \\
Internal capsule & 0 & 1 \\
Basal ganglia & 0 & 1 \\
Cerebellum & 1 & 0 \\
\hline
\end{tabular}

In five cases more than one anatomical site was affected.

Table 3 Fracture type and laterality in cases studied

\begin{tabular}{lll}
\hline Fracture type & Right side & Left side \\
\hline Subcapital & 1 & 1 \\
Transcervical & 0 & 0 \\
Intertrochanteric & 6 & 2 \\
Total & 7 & 3 \\
\hline
\end{tabular}

Table 4 Causes of death in cases studied

\begin{tabular}{llll}
\hline Cause of death & $\begin{array}{l}\text { All } \\
\text { cases }\end{array}$ & Men & Women \\
\hline Bronchopneumonia & 5 & 4 & 1 \\
Ischaemic heart disease & 4 & 0 & 4 \\
Calcific aortic stenosis & 1 & 1 & 0 \\
\hline
\end{tabular}

$14.9 \%$ (range $5 \cdot 8-22.9$ ), and if the two highest values $(22.9 \%$ and $20.4 \%)$ are excluded then the mean value was $9 \cdot 8 \%$ (range $5 \cdot 8-13 \cdot 4$ ). There was no histological evidence of osteomalacia or osteitis fibrosa in any of the cases.

\section{Discussion}

Osteoporosis is commonly believed to be an important risk factor in patients who suffer fractures of the proximal femur. Not every osteoporotic subject, however, has a fracture nor, indeed, is every person who suffers a fracture an osteoporotic. Published reports dealing with the issue of patients with fractures being appreciably more osteoporotic than age matched controls was recently reviewed by Cummings. ${ }^{3} \mathrm{He}$ concluded that, although the most rigorously designed studies observed less bone mass in patients with fractures, the differences from controls were usually small and overlapping. Aitken ${ }^{4}$ reported that a series of 200 women with a fracture of the femoral neck after minor trauma had bone mass measurements similar to those of a control population of normal women, and $16 \%$ were not osteoporotic. It has also been suggested that osteomalacia may be a contributory factor in a large number of cases. ${ }^{5-9}$ In contrast, two more recent Australian studies reported the absence of osteomalacia in patients with fracture of the femoral neck. ${ }^{1011}$ The idea that diminished bone quantity is the major determinant of femoral neck fracture cannot, therefore, be wholly accepted. It has been recognised that postural instability causing a fall is a common event in relation to the fracture. ${ }^{12}$ Aitken ${ }^{4}$ believed that postural instability was the major determinant and that the presence of osteo- 
porosis dictates the type of fracture (usually intertrochanteric) that occurs.

Brocklehurst et $\mathrm{al}^{12}$ performed a clinical study of 384 patients with fracture of the neck of femur and compared them with 226 controls. Forty three per cent of the patients with fracture had neurological disease $(12 \%$ had a stroke, $12 \%$ had the chronic brain syndrome, $6 \%$ had parkinsonism, and $13 \%$ had other neurological diagnoses). No information was given about the laterality of the lesions and there were no morbid anatomical studies.

Our series of cases is interesting from several viewpoints. There were lateralised intracerebral lesions, and in all instances the fractured femoral neck was on the contralateral side of the body. We believe that there was acute (the majority) or chronic hemiparesis and speculate that the patients fell towards and on to the side of the fracture. We further speculate that there was loss of muscle tone associated with the hemiparesis, allowing the weight of the body to act on the femoral head against the femoral neck, thus causing it to break. In several cases superficial abrasion and bruising of the knee and lower leg on the same side as the fracture had occurred. In case 1 an eyewitness confirmed that the patient had fallen on to the side of the fracture.

The two most noteworthy cases were the men with substantial trabecular bone volumes $(22.9 \%$ and $20.4 \%$ ), who cannot be regarded as being osteoporotic and who sustained subcapital fractures. In the remainder in whom the trabecular bone volume was known all had intertrochanteric fractures and were osteoporotic. These observations are compatible with Aitken's findings.

Most of the fractures (7:3) were right sided. We were not able to establish if all of these patients were right handed, although most seem to have been. There is a clear record that the three patients who sustained left sided fractures were left handed. We therefore tentatively suggest that these patients fall on to their preferred side if that is the side of weakness. In three cases the intracerebral lesions (although substantial in an anatomical sense) were not suspected clinically at the time of presentation with the fracture. In two of these (cases 5 and 8 ), in which the infarcts were clearly old morphologically and preceded the fractures, there were clear histories of clinical episodes of stroke some 12 and 18 months previously with definite, albeit mild, chronic hemiparasis. In the third case (4) the patient was quite ill at presentation, having sustained a recent infarct, and signs of hemiparesis were not detected. Internal fixation was performed after one week and the patient died two days later. It was thought that the cerebral infarct was more likely to have occurred at or about the time of the fracture than later at the time of operation. There is still the possibility, however, that the infarct occurred between the fracture and the oper $\stackrel{0}{5}$ ation. In most cases, however, we feel confident tha? the intracerebral lesions caused a fall that resulted in fracture and could find no evidence to support the alternative hypothesis that the fracture caused the vascular intracerebral lesions.

Our conclusion is that intracerebral lesions are important risk factors in fractured neck of femuro When the intracerebral lesion is acute there is loss of protective muscle tone and non-osteoporotic subjects are at risk as substantial body weight may act through the proximal femur in such a way as to cause a frac $\vec{\omega}$ ture. In cases of chronic hemiparesis there may alse be a tendency to trip on the affected side, and there is also the possibility that the hemiparetic lower limbi may have a lower bone mass than the contralaterabo limb.

We thank Mrs Anne Mellor for typing the manu응 script. John McClure is in receipt of research grants from the North West Regional Health Authority, the Foundation for Age Research, and the Arthritis ance Rheumatism Council for Research.

\section{References}

${ }^{1}$ Lewis AF. Fracture of the neck of femur: changing incidence. Br Med J 1981;283:1217-20.

${ }^{2}$ Katz S, Herple KG, Downs TD, et al. Long term course of 1470 patients with fracture of the hip. Surg Gynecol Obster®远
$1967 ; 124: 1219-30$.

${ }^{3}$ Cummings SR. Are patients with hip fractures more osteoporotic? Am J Med 1985;78:487-94.

${ }^{4}$ Aitken JM. Relevance of osteoporosis in women with fracture of the femoral neck. Br Med J 1984;288:597-601.

${ }^{5}$ Chalmers J, Conacher WDH, Gardner DL, Scott PJ. Osteomalacia-a common disease in elderly women. $J$ Bone Joint Surg 1967;49B:403-23.

${ }^{6}$ Jenkins DHR, Roberts JG, Webster D, Williams EO. Osteo-음 malacia in elderly patients with fracture of the femoral neck? $J$ Bone Joint Surg 1973;55B:575-80.

${ }^{7}$ Aaron JE, Gallagher JC, Anderson J, et al. Frequency of osteo-윽 malacia and osteoporosis in fractures of the proximal femur. Lancet 1974;i:229-33.

${ }^{8}$ Faccini JM, Exton-Smith AN, Boyde A. Disorders of bone and fractures of the femoral neck. Lancet 1976;i:1089-92.

${ }^{9}$ Sokoloff L. Occult osteomalacia in American (USA) patients with fractures of the hip. Am J Surg Pathol 1978;2:21-9.

${ }^{10}$ Evans RA, Ashwell JR, Dunstan CR. Lack of metabolic bone $\mathrm{G}$ disease in patients with fracture of the femoral neck. Aust NZ $\mathrm{JN}$ Med 1981;11:158-61.

${ }^{11}$ Wicks M, Garrett R, Vernon-Roberts B, Fazzalari N. Absence of metabolic bone disease in the proximal femur in patients with fracture of the femoral neck. J Bone Joint Surge 1982;64B:319-22.

12 Brocklehurst JC, Exton-Smith AN, Lempert Barber SM, Hunt LP, Palmer MK. Fracture of the femur in old age: a two-centre study of associated clinical factors and the cause of the fall. Age and Ageing 1978;7:7-15.

Requests for reprints to: Dr J McClure, Department of $\frac{\rho}{\mathbb{D}}$ Histopathology, UHSM, Nell Lane, West Didsbury, Manchester M20 8LR, England. 